\title{
Uji Daya Hidup Bakteri Asam Laktat Dari Usus Itik Pada Media Tumbuh Dengan Penambahan Variasi Konsentrasi Molasis
}

\section{Test Viability Of Lactic Acid Bacteria From Gut Duck On Media Grows With Addition Variation Of Molasses Concentration}

\author{
Rudy Sutrisna $^{1}$, Christina Nugroho Ekowati ${ }^{2}$, Riska Damayanti ${ }^{3}$ \\ ${ }^{1}$ Dosen Jurusan Peternakan Fakultas Pertanian, Universitas Lampung \\ ${ }^{2}$ Dosen Jurusan Biologi FMIPA, Universitas Lampung \\ ${ }^{3}$ Mahasiswa Jurusan Biologi FMIPA, Universitas Lampung \\ E-mail : rudysutrisna65@yahoo.co.id
}

\begin{abstract}
This study aims to determine differences in the viability of Lactic Acid Bacteria (LAB) isolates on MRS medium supplemented with various concentrations molasses. Concentration variation molasis used as controls were $0 \%, 1 \%, 2 \%$ and $3 \%$. Variation of time incubation on each of the media that is 0 hours, 24 hours, 48 hours and 72 hours. The viability of each isolate was viewed with the population of Log (cells $/ \mathrm{ml}$ ) which grow on the medium and the number of generations and time of generations. The results showed that the concentration molasses added to MRS affect the viability of $L A B$. Concentration of $1 \%$ makes $L A B$ better viability than controls. Total population continues to increase at the end of the incubation with a yield of 1.17 generations in time 20.46 hours/generation. In contrast to controls, reduced population size at the end of the incubation so as not to produce a generation. LAB viability in addition molasses $2 \%$ and $3 \%$ live on 48 hours of incubation. This is indicated by the number of population increased at 48 hours of incubation, and then decreased at the end of incubation. The addition of concentration variation in the types of bacteria showed different viability. At B1 adding molasses $2 \%$ and $3 \%$ live on 48 hours of incubation and control can only live on a 24 hours incubation, whereas the B3, the control can remain alive at 48 hours of incubation. In contrast to the controls on B4 can survive on 48 hours of incubation, whereas the addition of $3 \%$ molasses can only live on a 24 hours incubation.
\end{abstract}

Key words : Lactic Acid Bacteria/LAB, Molasses, Viability,

Diterima: 16 Oktober 2015, disetujui 19 Desember 2015

\section{PENDAHULUAN}

Mikroba memerlukan nutrisi yang berupa unsur-unsur: karbon, nitrogen, hidrogen, oksigen, sulfur, zat besi dan sejumlah kecil logam lainnya. Apabila kekurangan sumber-sumber nutrisi tersebut akan mempengaruhi pertumbuhan mikroba (Hajoeningtijas, 2012). Pertumbuhan dan perkembangan BAL membutuhkan nutrisi seperti asam amino, vitamin (B1, B6, B12 dan Biotin), purin dan pirimidin. Sebagai sumber karbon salah satunya molasis (Surono, 2004). Molasis diperlukan karena mengandung gula yang terdiri dari sukrosa $30-40 \%$, glukosa $4-9 \%$, dan fruktosa 5-12\%. Selain itu, molasis juga mengandung biotin, asam pantotenat, tiamin, fosfor, dan sulfur (Hidayat dan Suhartini, 2006). 

Kadar molasis yang digunakan disesuaikan dengan kebutuhan, karena bentuk molasis yang kental akan meningkatkan tekanan osmosis pada substrat. Apabila tekanan osmotik tinggi akan menyebabkan sel bakteri lisis dan pertumbuhan akan terhenti (Campbell et al., 2010). Untuk itu digunakan variasi konsentrasi molasis yang relatif rendah dengan kadar di bawah 5\% yaitu 1\%, 2\%, dan 3\% sebagai formulasi perlakuan. Hasil penelitian Supriyanto et al., (2010), konsentrasi molasis $2 \%$ adalah konsentrasi terbaik untuk pertumbuhan Lactobacillus plantarum.

\section{METODE}

Penelitian dilaksanakan di Laboratorium Mikrobiologi Fakultas MIPA Biologi Universitas Lampung dari bulan Januari - Maret 2015.

Alat yang digunakan selama penelitian adalah tabung reaksi, tabung anaerobic jar, gelas ukur, bunsen, vortex, backer glass $(50 \mathrm{ml}, 250 \mathrm{ml})$, cawan petri, erlenmeyer $(50 \mathrm{ml}, 100 \mathrm{ml}, 500 \mathrm{ml})$, hot plate, inkubator, laminar air flow, mikro pipet, mikro tip, oven. Bahan yang digunakan selama penelitian adalah Isolat bakteri usus itik (B1, B3 dan B4 ) yang diperoleh dari koleksi isolate (Sutrisna, 2010) disimpan di Laboratorium Mikrobiologi FMIPA Unila, media deMan Rogosa and Sharpe (MRS) Broth, NaCl steril, dan Molasis.

Variasi konsentrasi molasis yang digunakan yaitu $0 \%$ sebagai kontrol, $1 \%, 2 \%$, dan $3 \%$. Waktu inkubasi yang digunakan pada masing-masing media yaitu 0 jam, 24jam, 48jam dan 72 jam. Daya hidup isolat dilihat berdasarkan jumlah koloni ( $\mathrm{sel} / \mathrm{ml})$. Jumlah koloni yang didapatkan kemudian dianalisis secara deskriptif.

Isolat yang telah berumur 48 jam diambil $1 \mathrm{ml}$ diinokulasikan ke dalam $9 \mathrm{ml}$ MRS Broth steril, kemudian diinkubasi selama 48 jam. Setelah inkubasi, kultur digunakan sebagai starter. Medium tumbuh yang telah ditambahkan molasis kemudian diinokulasi dengan strater sebanyak $1 \mathrm{ml}$. Setelah itu, diingkubasi selama 0 jam hingga 72 jam.

\section{HASIL DAN PEMBAHASAN}

Hasil uji daya hidup bakteri asam laktat menunjukkan penambahan molasis memberikan pengaruh terhadap viabilitas Bakteri Asam Laktat (BAL), penambahan molasis 1\% menjadikan viabilitas BAL dapat hidup 72 jam inkubasi dibandingkan kontrol. Hal ini berdasarkan jumlah populasi awal dibandingkan dengan populasi akhir inkubasi. Populasi awal Isolat B1 pada konsentrasi molasis $1 \%$ yaitu 7,43 Log sel/ml, sedangkan pada akhir inkubasi yaitu 8, $71 \mathrm{Log} \mathrm{sel} / \mathrm{ml}$. Berbeda dengan kontrol, jumlah populasi berkurang pada akhir inkubasi. Selain konsentrasi $1 \%$, viabilitas bakteri asam laktat pada penambahan molasis $2 \%$ dan $3 \%$ dapat hidup pada 48 jam inkubasi. Hal ini ditunjukkan jumlah populasi bertambah pada 48 jam inkubasi, kemudian berkurang pada akhir inkubasi (Gambar 1).

Daya hidup isolat B3 berbeda dengan isolat B1. Molasis yang ditambahkan sebanyak 2\% menjadikan isolat B3 dapat hidup selama 48 jam inkubasi, jumlah populasi bertambah pada jam ke-48 yaitu 9,32 Log $\mathrm{sel} / \mathrm{ml}$. Pada penambahan molasis 3\% jumlah populasi juga bertambah pada jam ke-48 yaitu 9,29 Log $\mathrm{sel} / \mathrm{ml}$. Perbedaan antara isolat B3 dengan B1 terlihat pada jumlah populasi yang tumbuh di dalam kontrol (MRS). Isolat B3 dalam Kontrol dapat hidup selama 48 jam inkubasi, isolat B1 setelah 24 jam inkubasi jumlah populasi berkurang (Gambar 2).

Isolat B4 menunjukkan daya hidup berbeda dari isolat B1 dan B3 dengan adanya penambahan molasis. Isolat B4 dengan penambahan molasis $2 \%$ jumlah populasi bertambah pada jam ke-48 yaitu 8,87 Log sel/ml, namun pada akhir inkubasi jumlah populasi berkurang. Hal ini berbeda dengan isolat B4 
dalam penambahan molasis 3\% dapat hidup pada 24 jam inkubasi, kemudian jumlah populasi berkurang hingga akhir inkubasi (Gambar 3).

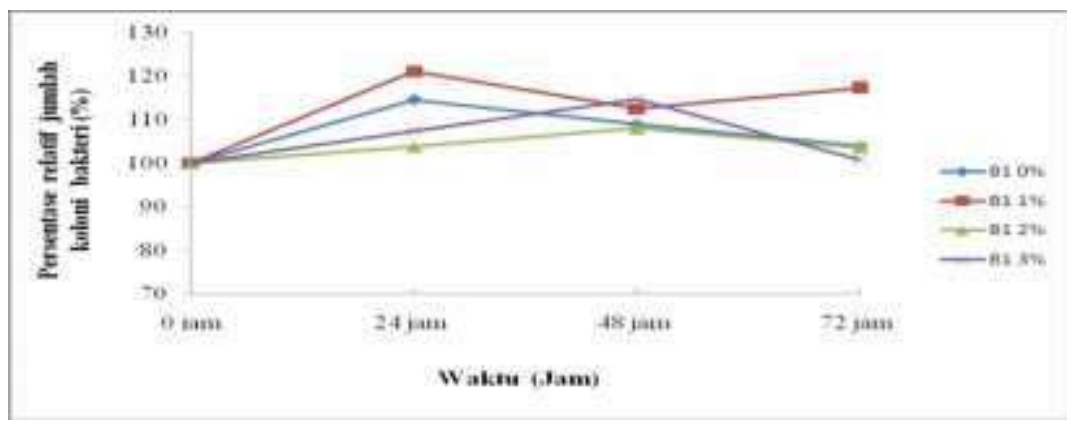

Gambar 1. Populasi B1 pada media tumbuh yang ditambah molasis

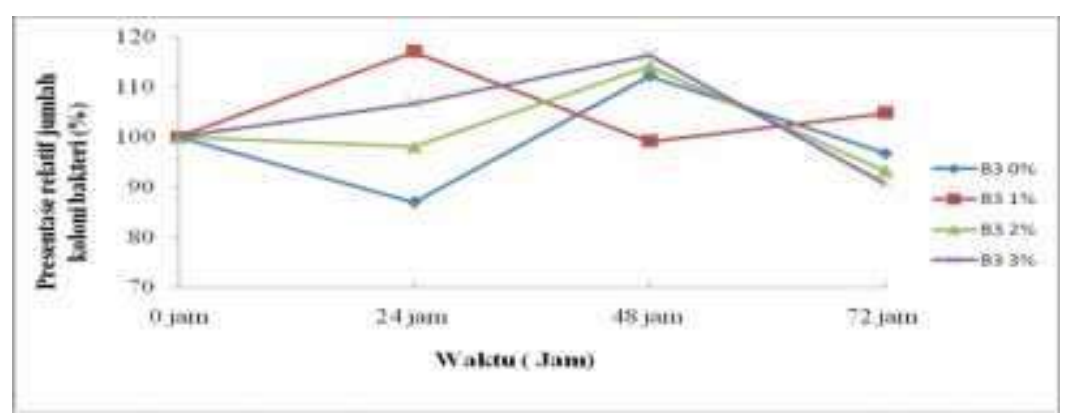

Gambar 2. Populasi B3 pada media tumbuh yang ditambah molasis

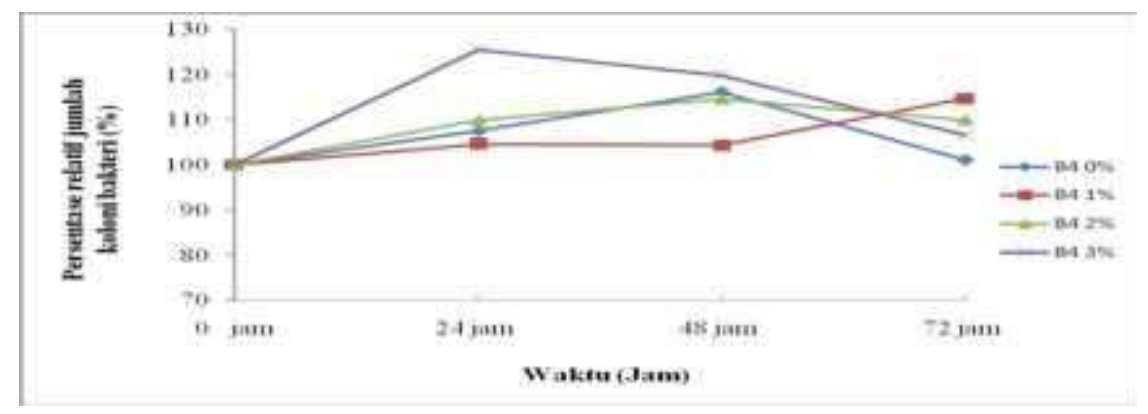

Gambar 3. Populasi B4 pada media tumbuh yang ditambah molasis

Penambahan molasis memberikan pengaruh terhadap daya hidup bakteri asam laktat. Penambahan molasis dengan konsentrasi molasis $2 \%$ dan $3 \%$ daya hidup isolat B1 sampai jam ke-48 dan konsentrasi molasis $1 \%$ masih terjadi pembelahan sel pada akhir inkubasi. Isolat B1 pada medium tumbuh (MRS) mengalami penurunan jumlah populasi pada jam ke 24. Penambahan populasi bakteri menunjukkan adanya pertumbuhan (Sundararaj et al.,2004). Sebagai hasil pertambahan ukuran dan pembelahan sel maka terjadi pertumbuhan populasi mikroba. Pada saat perbanyakan bahan inti ukuran dan massa sel yang asli (sel induk) bertambah, dan secepatnya membagi dalam dua sel (sel anak). Waktu yang dibutuhkan oleh bakteri untuk membelah ini disebut waktu generasi, dan sangat bervariasi tergantung dari spesies dan kondisi pertumbuhan (Pelczar dan Chan, 2005). 
Penambahan molasis dapat mempengaruhi viabilitas isolat BAL karena menurut Toharisman dan Santosa (1999) molasis merupakan media pertumbuhan yang kaya gula, terdiri dari sukrosa 30-40\%, glukosa 4-9\% dan fruktosa 4-9\%. Selain gula, terdapat senyawa organik lain yaitu Biotin 2\%, Cholin 8,8\%, Asam folat $0,35 \%$, Niacin $23 \%, \mathrm{~K} 2 \mathrm{O}, \mathrm{CuO}, \mathrm{MgO}$ dan $\mathrm{NaO}$. Masing-masing unsur penyusun molasis memiliki fungsi penting dalam pertumbuhan. Pertumbuhan meliputi proses yang kompleks, diawali dengan masuknya nutrisi ke dalam sel, kemudian nutrisi diubah menjadi energi dan pembentukkan organel sel. Selanjutnya digunakan untuk replikasi kromosom, setelah itu terjadi pembelahan sel menjadi dua sel anakan. Kemudian terjadi peningkatan jumlah dan ukuran sel (Moat et al., 2002). Pelczar et al.,(1993) menyatakan gula merupakan nutrien utama sel yang digunakan untuk respirasi sel atau sumber metabolisme utama. Metabolisme dapat menghasilkan energi yang diperlukan untuk sistem kerja sel, sintesis organel sel dan untuk membentuk generasi baru. Kim dan Gadd (2008) menambahkan biotin dapat digunakan oleh bakteri sebagai penyusun enzim karboksilase dan mutase. Asam folat menjadi bagian dari tetrahydro folat, kemudian unsur-unsur lain seperti $\mathrm{K}^{+}, \mathrm{Na}^{+}, \mathrm{Mg}^{+}$sebagai sumber ion untuk menyeimbangkan larutan yang berperan dalam memfasilitasi molekul menyeberangi membran sel dan sebagai kofaktor enzim (Moat et al., 2002). Medium tumbuh BAL juga memiliki nutrisi yang mencukupi sehingga dengan penambahan molasis $1 \%$ dapat membuat viabilitas BAL lebih lama.

Masing-masing isolat memiliki daya hidup yang berbeda akibat penambahan variasi konsentrasi molasis. Variasi konsentrasi molasis $2 \%$ dan 3\% dapat memberi pengaruh yang berbeda pada masingmasing isolat. Pada penambahan molasis 1\%, isolat B1, B3 dan B4 tetap dapat menghasilkan generasi pada akhir inkubasi. Perbedaan daya hidup pada masing-masing konsentrasi karena komposisi molekul molasis sangat berpengaruh terhadap tekanan osmotik medium. Menurut Lodish et al., (2004) bahwa tekanan osmotik sangat berpengaruh terhadap masuknya nutrisi ke dalam sel. Gas dan $\mathrm{CO} 2$ serta senyawa polar seperti urea dan etanol yang dapat melewati membran dengan cara difusi pasif. Membran sel sangat permeabel dengan molekul-molekul ini, sehingga dapat dengan bebas masuk ke dalam membran. Hasil penelitian menunjukkan penambahan molasis pada konsentrasi $1 \%$ merupakan konsentrasi terbaik. Nutrisi seperti glukosa, sukrosa dan nutrisi dengan molekul yang besar lainnya, masuk ke dalam sel melalui transport aktif dan difusi terfasilitasi. Proses ini dipengaruhi oleh tekanan osmotik antara dua sisi, konsentrasi larutan di dalam sel lebih pekat dari konsentrasi di luar sel. Transport nutrien ini membutuhkan energi karena harus melawan gradien konsentrasi dari konsentrasi yang rendah ke konsentrasi yang tinggi (Pelczar et al., 1993). Bakteri Asam Laktat dapat menyerap nutrisi dengan baik karena memiliki tekanan osmotik yang sesuai, sehingga transport nutrisi berjalan lancar. Berbeda dengan konsentrasi lainnya yaitu $2 \%$ dan 3\% larutannya lebih kental dan tekanan osmotiknya lebih tinggi dibandingkan dengan konsentrasi $1 \%$. Hal ini menyebabkan transport nutrient terganggu, bakteri tidak dapat menyerap nutrisi dengan baik, sehingga bakteri tidak dapat bertahan pada akhir inkubasi. Konsentrasi molasis $2 \%$ dan $3 \%$ dapat menjadi hipertonik terhadap sel bakteri, yang mengakibatkan molekul-molekul seperti air, gas dan alkohol dapat bebas keluar dari dalam sel dan terjadi plasmolisis (Campbel et al., 2010)

\section{KESIMPULAN}

1. Penambahan molasis konsentrasi $1 \%$ pada medium tumbuh menjadikan daya hidup BAL lebih baik dibandingkan kontrol (MRS). Pada B1, B3 dan B4 jumlah populasi bertambah pada 72 jam inkubasi.

2. Isolat B1, B3, dan B4 memiliki viabilitas yang berbeda jika ditambahkan molasis dengan konsentrasi yang berbeda. 


\section{UCAPAN TERIMAKASIH}

Penulis menyampaikan terima kasih kepada Kemenristek dan Pedidikan Tinggi yang telah membiayai penelitian ini melalui Proyek Penelitian Hibah Bersaing tahun 12015 dari rencana 2 tahun.

\section{DAFTAR PUSTAKA}

Campbell, Reece dan L. Mitchell. 2010. Biologi Edisi Kedelapan. Jilid 1. Erlangga. Jakarta

Hajoeningtijas, D. O. 2012. Mikrobiologi Pertanian. Graha ilmu. Yogyakarta Hidayat, N.M.C dan Suhartini. 2006. Mikrobiologi Industri. Andi. Jakarta

Hidayat dan Suhartini, 2006. Mikrobiologi Industri. Andi. Jakarta

Kim, H. B and M. G, Gadd. 2008. Bacterial Physiology and metabolism. Cambridge university press. New York

Lodish, H., A. Berk, P. Matsuaira, C. A. Kaiser, M. Krieger, M. P. Scott, S. L. Zipursky. J, Darnell, J. 2004. Molecular Cell Biology. Fifth Edition.WH Freeman. New york

Moat, G.A., W. J. Foster and P.M. Spector. 2002. Microbial Physiology. fourth edition. Wiley-Liss. United States of Amerika.

Pelczar, J. M., E. S. C. Chan, R. K. Noel and D. E. Diane. 1993. Microbiology Concept and Application. MC Graw Hill. New York

Pelczar, J. M dan E. S. C. Chan. 2005. Dasar-dasar Mikrobiologi. Jakarta. UI Press Sumarsih, S. 2003. Mikrobiologi Dasar. Universitas Pembangunan Nasional Veteran. Yogyakarta

Sundararaj, T. S., N. Anthoniraj, Kannan and S. M. Muthukaruppan. 2004. Microbiology. Tamil Nadu Text Book Corporation. Chennai.

Surono, I.S., 2004. Probiotik, Susu Fermentasi dan Kesehatan. Tri Cipta arya Jakarta.

Sutrisna, R., S. Nurjanah. 2010. Isolasi non-starch Polysacharides sebagai Prebiotik dan Bakteri sebagai Probotik dalam Sistem Pencernaan Itik. Laporan Penelitian Hibah Bersaing Tahun 2010. Fakultas Pertanian Universitas Lampung Bandar Lampung.

Supriyanto, Augus, A.N. Heryani, dan Ni'matuzahroh. 2012. Studi Viabilitas dan Pola Pertumbuhan Bacillus megaterium pada Konsentrasi Molase dan Waktu Inkubasi yang Berbeda. Universitas Airlangga.

Toharisman, A. dan H. Santoso. 1999. Mutu Bahan Baku dan Preparasi Medium. Dalam Pelatihan Teknologi Alkohol. Pusat Penelitian Perkebunan Gula Indonesia. Pasuruhan. 